\title{
PERIODICITÁS A TERMÉSZETTUDOMÁNYOKBAN - MENGYELEJEV ÖRÖKSÉGE
}

\section{PERIODICITY IN NATURAL SCIENCES - MENDELEEV'S LEGACY}

\author{
Maksay Gábor \\ a biológiai tudomány doktora, Természettudományi Kutatóközpont \\ maksay.gabor@ttk.hu
}

\section{ÖSSZEFOGLALÁS}

Dmitrij Mengyelejev 150 éve fedezte fel a kémiai elemek periodicitását. A jubileum kereteit kiterjesztve, áttekintjük a természettudományokban felfedezett periodicitásokat, elsősorban a fizikai kémiában, biokémiában és biológiában. Az élettanilag fontos elemek elkülönülő csoportokban helyezkednek el a periódusos rendszerben, mely rendszer a kémia oktatásának mindmáig alapja. A természet biopolimerei, a fehérjék és nukleinsavak gazdaságosan épülnek fel; homológ építőkövekből, periodikus láncokon át; növekvő stabilitással, szimmetriával és hierarchiával. A fehérjék negyedleges komplexei az alegységek száma és szimmetriájuk szerint periódusos rendszerbe illeszthetők. Az időbeli periodicitás chemoton modellje kapcsolatot teremt a kémiai és biológiai evolúció között. A biofázis ciklikus folyamatai a geofázis periódusaihoz illeszkednek. Bizonyos szervek (például: szárny, szem) rekurrens módon, periodikusan és hasonló formában újra megjelennek a törzsfejlődés különböző szintjein. A fizikai anyagforma belső kölcsönhatásainak periódusait és frekvenciáit a biológiai anyagforma felé haladva egyre inkább elfedik a környezeti kölcsönhatások.

\begin{abstract}
Dmitri Mendeleev discovered the periodicity of chemical elements 150 years ago. Beyond the scope of the jubilee we have overviewed periodicities discovered in natural sciences, particularly in physical chemistry, biochemistry and biology. The physiologically important elements are situated in separate groups in the periodic table which has since been the basis of teaching chemistry. Nature builds up its biopolymers, proteins and nucleic acids economically; through periodic chains; with increasing stability, symmetry and hierarchy. The quaternary protein complexes can be put in a periodic table according to the number of their subunits and symmetry. The chemoton model of temporal periodicity is a link between chemical and biological evolutions. Cyclic processes in the biophase fit in the periods of the geophase. Certain organs (e.g. wing and eye) show up in recurrent manner, periodically and in similar forms at different levels of evolution. The periods and frequencies of the physical type of matter are disguised by environmental interactions more and more towards the biological type of matter.
\end{abstract}


Kulcsszavak: elemek periódusos rendszere, Mengyelejev, fehérjék, DNS, szimmetria

Keywords: periodic table of chemical elements, Mendeleev, proteins, DNA, symmetry

\section{FIZIKAI KÉMIAI PERIODICITÁS}

A kémiai elemek periódusos rendszere, melyet Dmitrij Ivanovics Mengyelejev orosz kémikus ismert fel 1869-ben, mindmáig a kémia oktatásának alapvető eszköze. De vajon átlátjuk-e egészen tudományos és kulturális jelentőségét? Az UNESCO az idei évet a kémiai elemek periódusos rendszerének szentelte a másfél évszázados jubileum tiszteletére (1. ábra). A Nature és Science 2019. januári számaiban több cikk is foglalkozik a jubileummal. Az Általános és Alkalmazott Kémia XXI. Jubileumi Mengyelejev Kongresszusát Szentpéterváron tartották 2019 szeptemberében. A Nemzetközi Csillagászati Unió pedig The Periodic Table through Space and Time címmel tartott kapcsolódó szimpóziumot.

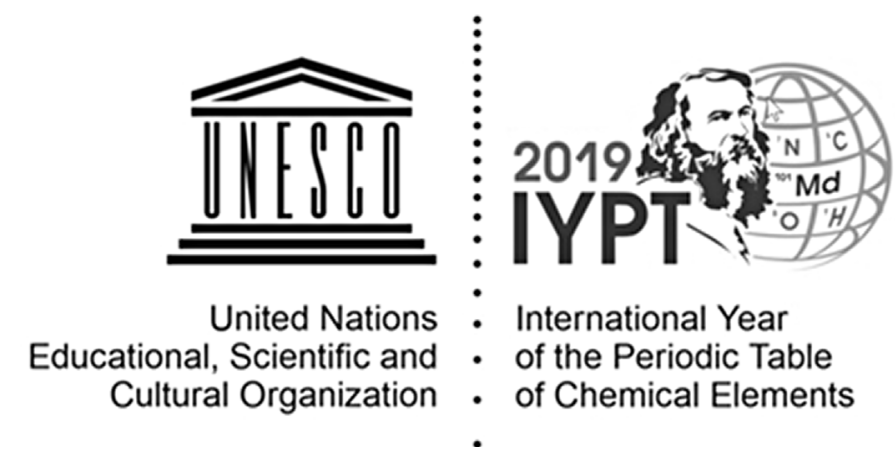

1. ábra. Az UNESCO emblémája a kémiai elemek periodikus rendszere éve és Mengyelejev tiszteletére (URL1)

A tudományos kutatás igyekszik a felismeréseket és összefüggéseket rendszerbe illeszteni. Carl von Linné a 18. században rendszerbe foglalta a növényeket és állatokat. Miután pedig a 19. században sikerült világosan megkülönböztetni a kémiai elemeket és vegyületeket, Mengyelejev felismerte, hogy az elemek tulajdonságai periodikusan ismétlődnek az atomtömeg függvényében. Ennek alapján sorokba és oszlopokba rendezte az akkor ismert hatvanhárom elemet. Mások hasonló rendszereit meghaladóan Mengyelejev a periódusos rendszere alapján megjósolta új elemek létezését és tulajdonságait is. Ezeknek az elemeknek a felfedezése hamarosan igazolta rendszere érvényességét. Voltak persze ellentmon- 
dónak látszó felfedezések is: például a nemesgázok számára új oszlopot kellett a rendszerbe illeszteni.

Mengyelejev valóban a kémia alapvető rendszerét ismerte fel. A rendszer alapvető jellegzetessége a periodicitás, periodikusan változó paraméterek (atomsugár, ionizációs energia, elektronegativitás, elektronaffinitás, fémes jelleg) határozzák meg az elemek tulajdonságait és kémiai reaktivitását.

Sok természeti jelenség, folyamat ciklikus, meghatározott sorrendben és időben ismétlódik. Mengyelejev periódusos rendszere volt az első, amelyik az anyag szerkezetében és minőségében mutatott ki periodicitást. Az aktinoidák bővülésével ma már 118 elemet tartalmaz a periódusos rendszer. De ezeknek a magfúzióval elóállított szupernehéz elemeknek az élettartama rendkívül rövid, és tulajdonságaik periodicitása gyengül (Scerri, 1998). A periódusos rendszernek számos változata van. Kisebb-nagyobb anomáliáinak értelmezése apróbb módosulásokat eredményezhet még, de gyakorlatilag véglegesnek tünik.

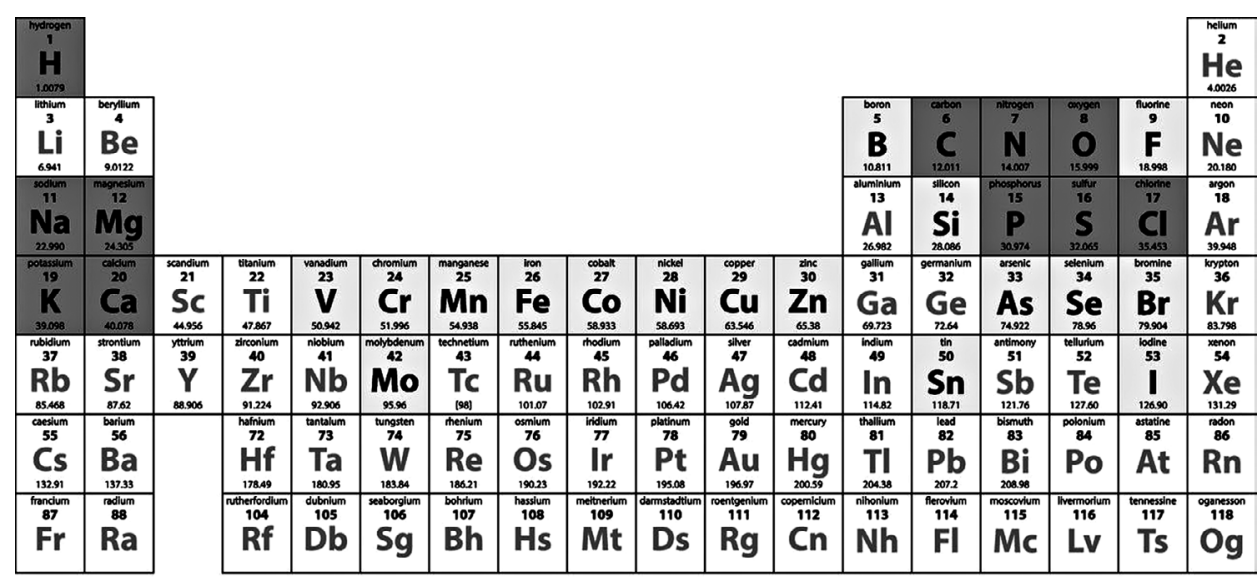

\begin{tabular}{|c|c|c|c|c|c|c|c|c|c|c|c|c|c|c|}
\hline 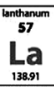 & $\begin{array}{c}58 \\
\mathrm{Ce}\end{array}$ & $\begin{array}{l}\mathbf{5 9} \\
\mathbf{P r}\end{array}$ & $\begin{array}{l}\mathbf{6 0} \\
\mathbf{N a} 24\end{array}$ & Pm & $\begin{array}{l}\text { somantium } \\
\mathbf{6 2} \\
\mathrm{Sm}_{150.36}\end{array}$ & $\begin{array}{l}\text { europlum } \\
63 \\
\text { Eu } \\
151.96\end{array}$ & $\begin{array}{l}\text { gadolinhum } \\
\text { G4 } \\
\text { Gd } \\
\text { 1572.25 }\end{array}$ & $\begin{array}{c}\text { terblum } \\
\mathbf{6 5} \\
\mathbf{T b} \\
\text { issegs }\end{array}$ & $\begin{array}{l}\text { dyppossum } \\
\text { Dy } \\
\text { Dy } \\
16250\end{array}$ & $\begin{array}{l}\text { holminum } \\
67 \\
\text { Ho } \\
16093\end{array}$ & $\begin{array}{l}{ }_{68}^{\text {estium }} \\
\mathrm{Er} \\
166,26\end{array}$ & $\begin{array}{l}\text { thullum } \\
\text { To9 } \\
T_{\text {is8993 }}\end{array}$ & 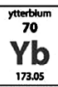 & \begin{tabular}{|l} 
Iutetum \\
$\mathbf{7 1}$ \\
$\mathbf{L u}$ \\
1749,9
\end{tabular} \\
\hline $\begin{array}{l}\text { sethium } \\
\text { Ag } \\
\text { AC }\end{array}$ & $\begin{array}{l}\text { thonum } \\
90 \\
\text { Th }\end{array}$ & 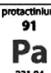 & $\begin{array}{c}\text { urnilum } \\
\mathbf{9 2} \\
\mathbf{U}\end{array}$ & $\begin{array}{l}\text { nepponvum } \\
9^{3} \\
\mathbf{N p}\end{array}$ & $\begin{array}{l}\text { purtonitum } \\
94 \\
\text { Pu }\end{array}$ & $\begin{array}{l}\text { Imercilum } \\
95 \\
\text { Am }\end{array}$ & \begin{tabular}{|c|} 
cunvum \\
$\mathbf{9 6}$ \\
$\mathrm{Cm}$
\end{tabular} & $\begin{array}{c}\text { benentum } \\
97 \\
\text { BK }\end{array}$ & $\begin{array}{c}\text { colromivom } \\
98 \\
\text { Cf }\end{array}$ & $\begin{array}{l}\text { ensrsentivem } \\
99 \\
\text { ES }\end{array}$ & $\begin{array}{l}\text { remivm } \\
100 \\
F m\end{array}$ & $\begin{array}{l}\text { menosenterum } \\
101 \\
\text { Mid }\end{array}$ & $\begin{array}{l}\text { noobllim } \\
102 \\
\text { No }\end{array}$ & $\begin{array}{l}\text { sereccum } \\
\text { 103 } \\
\text { Lr }\end{array}$ \\
\hline
\end{tabular}

2. ábra. A kémiai elemek periódusos rendszere és biokémiai relevanciája (Az esszenciálisan szükséges 28 elem szürke árnyalata mennyiségi viszonyaikat tükrözi az élő szervezetekben. A nyomelemek halványszürkék.)

(saját szerkesztés Jonsson et al., 2017 alapján)

Mengyelejev periódusos rendszere inspirálta Joseph John Thompson, Wolfgang Pauli és Niels Bohr atommodelljét fél évszázaddal később. Mai szemmel az atomszerkezet és elektronhéjainak ismeretében az atomok protonjaik száma, azaz 
rendszámuk alapján rendezhetők sorba, és az egyes elektronhéjak telítódése után kerülnek a következő sorba. A periódusos rendszer független változója menynyiségi jellegü lépcsőzetes függvény, a függő változó pedig a minőség változása periodikusan; úgy, hogy a hasonló tulajdonságúak azonos oszlopba kerülnek. A rendszer komplexitásában a hierarchia szintjeit az elektronhéjak (s, d, f, g, h, i) jelentik, mégpedig hagymahéjszerü elrendezésben: az első periódus az $s$ héj, a második a $d$ stb. Az elemek periódusos rendszere az atomok elektronkonfigurációjának periodicitását tükrözi. Az atom reaktivitását főképpen a külső héj vegyértékelektronjai, ezek a szimmetrikus vegyértékorbitálok határozzák meg.

Vegyületek (két- és háromatomos molekulák, aromás szénhidrogének) rendszerezését is megpróbálták. Kevés eredménnyel, mert itt a független változó nem lineárisan változik.

Figyelemre méltó, hogy az élővilág esszenciális alkotóelemei: szén, nitrogén, oxigén, foszfor és kén ( $\mathrm{C}, \mathrm{N}, \mathrm{O}, \mathrm{P}$ és $\mathrm{S})$, a hidrogén kivételével, azonos csoportban találhatók a periódusos rendszer jobb felső sarkában (2. ábra). Ugyanitt található a klór $(\mathrm{Cl})$, amely anionként esszenciális. Másrészt az esszenciális kationok elemei ( $\mathrm{Na}, \mathrm{K}, \mathrm{Mg}$ és $\mathrm{Ca}$ ) a rendszer bal oldalán tömörülnek, a hidrogén alatt, amelynek kationja hasonló tulajdonságú. A többi, különböző funkciójú elem is különálló csoportokat alkot a rendszerben. Ez a hasonló kémiai tulajdonságok megnyilvánulása hasonló funkciókban.

A periodicitás és gyakoriság kiegészítő fogalmak. Időben, a fizikában egzaktul, a reciprok periódus a frekvencia, az egységnyi időre jutó periódusok menynyisége. A szerkezeti és időbeli periodicitás összefüggése feltehetőleg az anyag kettős (korpuszkuláris és hullám-) természetéből ered. Például az elektron szimmetrikus pályákat tölt be, mindazonáltal perdülete van. Terveztek már alacsony hőmérsékleten csapdázott ionokkal tér-idő kristályokat is, amelyeknek szerkezete térben és időben periodikus (Liu-Dwi-Nugroho, 2012).

A fizikai folyamatok minden szintjén megfigyelhető a pontos frekvencia; az elemi részecskéktől a Naprendszerig.

\section{BIOKÉMIAI PERIODICITÁS}

A biológiai szervezetekben a fehérjék meghatározó helyzetben vannak. A szerkezeti proteinekben (kollagén, keratin, selyem) sok periodikusan ismétlődő aminosav-szekvencia található. A peptidlánc ismétlődő savamid kötéseiben a C- és $\mathrm{N}$-atomok vegyértékeinek szögpárai periodikusan ismétlődő másodlagos szerkezeteket (hélix, ß-redő) határoznak meg, amelyek - például hidrogénhidakkal harmadlagos szerkezetté feltekeredve rögzülnek. A funkcionális fehérjékben (transzkripciós faktorok, receptorok, ioncsatornák, hisztonok) szerkezeti domének ismétlődnek. A domén a fehérje harmadlagos szerkezetének funkcionális egysége; 
van például tetratrikopeptid, ankyrin és ß-propeller. Megpróbálták formalizálni a fehérjék másodlagos és harmadlagos kölcsönhatásait, hogy topológiájukat automatikusan lehessen definiálni és periódusos rendszerbe foglalni (Taylor, 2002).

A fehérjék szerkezeti hierarchiája sokrétü. Az alegységek (harmadlagos szerkezetű peptidláncok) egymással szimmetrikus kvaterner komplexeket hoznak létre (például: szuperhélix, csavart csavar). A szignaloszómáknak nevezett kvaterner komplexek nagy méretük miatt jelátviteli sejttestecskéknek tekinthetők (Maksay-Marsh, 2017). Sebastian E. Ahnert és munkatársai (2015) periódusos rendszerbe foglalták a kvaterner proteineket több száz szerkezet topográfiája és alegységeik kontaktfelületének elemzése alapján. Az egyik tengelyen különböző alegységeik száma szerepel, a másikon pedig szimmetrikus ismétlődéseik száma. Az egyes cellákban pedig sémás szerkezetük van. Azonos alegységek fej-láb kapcsolódással forgási szimmetriájú komplexeket képeznek, a fej-fej és láb-láb kapcsolódások pedig diéderes szimmetriát eredményeznek. Ez a szerkezeti periódusos rendszer már új szerkezetek predikciójára és az ismertek besorolásának korrekciójára is alkalmas (Ahnert et al., 2015).

A sejtmembránba ágyazott ioncsatornák és transzporterek felelősek a sejt ionháztartása, ingerelhetősége és anyagcseréje folyamataiért. Ezek a henger- és tükörszimmetrikus fehérjék periodikusan és ciklikusan váltakoznak nyitott és zárt állapotú szerkezetek között. Fizikai (elektromos) és kémiai inger (ligandumok kötődése) szimmetriasértő szerkezetváltoztatással hoz létre nyitott állapotot (Maksay-Tőke, 2014).

Általánosan megfogalmazható, hogy a hierarchia alacsonyabb szintjének szerkezeti tulajdonságai határozzák meg a hierarchia magasabb szintjének szerkezetét. Következésképp az új fehérjelánc feltekeredése (folding) meghatározott útvonalon közelít stabil natív szerkezetéhez. Ez aztán periodikusan oszcillál a funkcionális (például az előbbi nyitott és zárt) állapotok között.

A fehérjelánc periodikus ß-redői oda-vissza, párhuzamosan ß-lemezbe rendeződhetnek, majd növekvő hierarchiával és szimmetriával stabilizálódnak. Alzheimer-kórban és hasonló neurodegeneratív betegségekben ilyen szerkezetü $ß$-amiloid rostok keletkeznek az agyban. Ezek a fehérjék legstabilabb szerkezetei, amelyekböl nincs visszaút...

A nukleinsavak szerkezete a fehérjékhez hasonlóan periodikus és hierarchikus. Az elsődleges szerkezet a váltakozó dezoxiribóz (cukor) és foszfodiészter egységek láncolata. A cukorhoz négyféle nukleobázis (adenin, citozin, guanin és timin) kapcsolódik. A négyféle cukor-foszfát-bázis egység közös neve nukleotid. A másodlagos szerkezetben két lánc között a bázisok hidrogénhidakkal kapcsolódnak. A bázisok szerkezete csak timin-adenin és citozin-guanin párkapcsolatokat tesz lehetővé. A harmadlagos szerkezet a dupla hélix, amelyben a bázispárok csigalépcsőként helyezkednek el. A negyedleges szerkezetben a dupla hélixek tovább tekeredhetnek egymással (például szuperhélix). 
A transzpozon olyan DNS-szakasz, amelyik önmaga lemásolásával a DNS több helyén is beilleszkedve fokozza a periodicitást. A palindrom pedig olyan DNS-szakasz, amelyik visszafelé azonos sorrendü, tehát szimmetrikus. A DNS halmozottan előforduló, szabályos közökkel elválasztott rövid palindromikus ismétlődései (Clustered Regularly Interspaced Short Palindromic Repeats, CRISPR) a génszerkesztés beláthatatlan perspektíváit nyitották meg.

Összefoglalva, a természet legfontosabb biopolimerei (fehérjék, nukleinsavak, szénhidrátok) hasonló elvek szerint épülnek fel. Gazdaságosan, homológ építőkövekből, periodikus láncokon át; növekvő stabilitással, szimmetriával és hierarchiával jutnak el szinte végtelen szerkezeti változatosságig.

\section{BIOLÓGIAI PERIODICITÁS}

Gánti Tibor chemoton elmélete hidat képez a kémiai és biológiai periodicitás között (Gánti, 2002). A chemoton az élet minimálrendszere. Három autokatalitikus alrendszert tartalmaz sztöchiometrikusan, megszabott arányban csatolva. A chemoton önszerveződő fluid automata, amely stabil, szaporodik és evolúcióképes. Következésképpen az időbeli biológiai periodicitás a prebiotikus evolúcióból ered.

Az élö szervezetekben hasonlóan, periodikus és összehangolt körfolyamatokba rendeződik az önfenntartás, reprodukció, a szükséges vegyületek előállítása és lebontása. Az energiatermelés biológiai oxidációval történik, amely egymáshoz kapcsolódó periodikus folyamatokra épül. Például a gerincesek tüdeje periodikusan veszi fel az oxigént; a szív ciklikusan adja tovább a vér hemoglobinjához kötött oxigént a szerveknek, amelyekben a citrátciklus és a kapcsolódó oxidatív foszforiláció energiatároló vegyületek (ATP) szintéziséhez vezet.

A biológiai rendszereket és evolúciójukat befolyásolják a geoszféra és bioszféra ciklikus folyamatai: a cirkadián ciklus, az évszakok stb. Az élő szervezetek epigenetikus és periodikus hormonális szabályozással alkalmazkodnak a ciklikusan változó fény- és hőmérsékleti viszonyokhoz.

Kérdéses, hogy a biológiai periodicitás vizsgálatában mi tekinthető független változónak. Antonio Lima-de-Faria az evolúció és rendszertan alapján vizsgálta az egyes rendszertani csoportok funkcióit, tehát a minőségi változások periodicitását $(1997,2018)$. A független változóban tehát megjelenik az idő is. A biológiai evolúció rekurrens jellegét számos ismételten megjelenő szerv és funkció igazolja, például a lumineszcencia, látás, regeneráció, placenta, pénisz és a mentális képességek ismételten felbukkannak a törzsfejlődés különböző szintjein ( $\mathrm{Li}$ ma-de-Faria, 2018). A placenta eltérő komplexitású rendszertani szinteken jelenik meg: növényekben(!), gerinctelenekben és emlősökben, számos faj hasonló szárnyakkal repül, pedig a szervezettségük különféle. Lima-de-Faria $(1997,2018)$ a rekurrens evolúcióban laza periodicitást vél felfedezni. 
Nemkódoló RNS-ek szabályozzák a DNS-ek aktivitását, a fehérjékre átírást. A genomban kódolt bizonyos funkciók az életkörülmények változása következtében egyes fajoknál szükségtelenné válnak, és gátlódnak, másoknál újra előnyössé válhatnak, és expresszálódnak, kifejezésre jutnak. Így az evolúciónak nem kell újra és újra felfedezni, és müködésképtelen átmeneti formákon át stabilizálni egyegy funkciót. Úgy tűnik, hogy az evolúció szükség esetén (időközönként) a faj fenntartásához előnyös funkciókat expresszál (Lima-de-Faria, 2018).

Lima-de-Faria $(1997,2018)$ még tovább megy, és a periodikus rekurrenciát az elemek periódusos rendszerére és a feljebb említett elemcsoportosulásokra vezeti vissza. Okozati összefüggést lát az ásványok kristályszerkezeti és az élővilág morfológiai szimmetriái között is (Lima-de-Faria, 1997). Bilaterális tükörszimmetria jellemzi a kontakt ikerkristályokat és minden gerinces fajt. A természetben mindenhol megtalálható szimmetria az anyagszerkezet szimmetriájának megnyilvánulása. A jégkristályok hatfogású forgási szimmetriája például a $\mathrm{H}_{2} \mathrm{O}$-molekula térszerkezetéből következik. A molekuláris mimikri alapján különböző kémiai összetételü ásványok és makromolekulák vehetnek fel hasonló szerkezetet, és tölthetnek be hasonló funkciót. Bizonyos fajok szemlencséje nem fehérjéket (krisztallinokat), hanem ásványokat tartalmaz. Lima-de-Faria biológiai periódusos rendszere azonban predikciókra nem képes, és számos adattal kell még alátámasztani a létjogosultságát.

Bizonyos növény- és állatfajok tömegének ciklikus váltakozása is periodikus jelenség. Az észak-amerikai kabócák (Magicicada) tömeges felszaporodásának 13 és 17 éves periódusokba rendeződése hőmérsékleti változásoknak tulajdonítható (Ito et al., 2015). Már ökológiai periódusos táblázatokkal is próbálkoztak (Ferraro, 2013).

De mi is a gond a biológiai szerkezeti periodicitások kimutatása körül? Az anyagszerkezet mélyén ugyan bizonyosan ott lapul a periodicitás, de a szupernehéz kémiai elemek tulajdonságaiban már gyengül, mert a tulajdonságaikat meghatározó külső elektronok egyre jobban kikerülnek az atommag vonzó hatása alól. Az atommag belső, erős kölcsönhatásai determinisztikus törvényszerüségekben nyilvánulnak meg. Egy komplex biológiai rendszer tulajdonságait azonban nemcsak belső, hanem külső hatások (bioszféra, geoszféra és légkör) is befolyásolják. Minél jobban alárendelődnek a belső kölcsönhatások a környezeti hatásoknak, annál inkább elfedik valószínüségi törvényszerüségek a determinisztikusakat (Maksay, 2015).

Láthattuk, hogy a periodicitás kapcsolatban áll a szimmetria fogalmával. Geometriai megfogalmazással, a szimmetrikus szerkezetek szimmetriamüveletekre (például tükrözés) invariánsak. Az evolúció periodikus ismétlődésekkel fokozza a szerkezetek szimmetriáját és stabilitását. Modern biofizikai szerkezetvizsgálatok feltárták, hogy a biomakromolekulák müködését szimmetriasértő szerkezetváltozások váltják ki (Maksay-Tőke, 2014). 
A biológiai ismeretek rendszerezése Linné óta folyamatosan bővül. Mengyelejev óta pedig a rendszerezésben a periodicitást is figyelembe veszik (LiuDwi-Nugroho, 2012). A fizikai, kémiai, biokémiai és szerkezeti biológiai anyagformákban a tudomány sorra tárja fel a periodicitást. Amennyiben a szimmetria általános rendszerező elvnek is tekinthető, a biológiai periódusos rendszerekben - ha lesz valaha ilyen - a szimmetriára fontos szerep vár.

\section{IRODALOM}

Ahnert, S. E. - Marsh, J. A. - Hernández, A. et al. (2015): Principles of Assembly Reveal a Periodic Table of Protein Complexes. Science, 350, aaa2245. DOI: 10.1126/science.aaa2245

Ferraro, S. P. (2013): Ecological Periodic Tables: in Principle and Practice. Oikos, 122, 1541-1553. DOI: $10.1111 / j .1600-0706.2013 .00717 . x$

Gánti T. (2002): On the Early Evolutionary Origin of Biological Periodicity. Cell Biology International, 26, 729-735. DOI: 10.1006/cbir.2000.0668, https://www.researchgate.net/publication/11210935_On_the_early_evolutionary_origin_of_biological_periodicity

Ito, H. - Kakishima, S. - Uehara, T. et al. (2015): Evolution of Periodicity in Periodic Cicadas. Scientific Reports, 5, 14094. DOI: 10.1038/srep14094, https://www.nature.com/articles/srep14094

Jonsson, A. L. - Roberts, M. A. J. - Kiappes, J. L. et al. (2017): Essential Chemistry for Biochemists. Essays in Biochemistry, 61, 401-427. DOI: 10.1042/EBC20160094, http://essays.biochemistry.org/content/61/4/401

Lima-de-Faria, A. (1997): The Atomic Basis of Biological Symmetry and Periodicity. BioSystems, 43, 115-135. DOI: 10.1016/S0303-2647(97)01694-8

Lima-De-Faria, A. (2018): Periodic Tables Unifying Living Organisms at the Molecular Level: The Predictive Power of the Law Of Periodicity. World Scientific Press preview, https://books. google.hu

Liu, Y. - Dwi-Nugroho, A. (2012): The Social Semiotic Construction of Chemical Periodicity: A Multimodal View. Semiotica, 190, 133-151.

Maksay G. (2015): Quo vadis, tudományos megismerés? Magyar Tudomány, 176, 9, 1139-1145. http://www.matud.iif.hu/2015/09/16.htm

Maksay G. (2019): Kémiai és biológiai periodicitás; Mengyelejev öröksége. Biokémia, XLIII, 1, 42-49. http://www.mbkegy.hu/apps/mbkegy/resources/biokem/2019/2019_03.pdf

Maksay G. - Marsh, J. (2017): Signalling Assemblies: The Odds of Symmetry. Biochemical Society Transactions, 45, 599-611. DOI: 10.1042/BST20170009

Maksay G. - Tőke O. (2014): Asymmetric Perturbations of Signalling Oligomers. Progr. Biophys. \& Mol. Biol., 114, 153-169. DOI: 10.1016/j.pbiomolbio.2014.03.001, http://real.mtak.hu/21828/7/ Asymmetric_Signalling_MG_TO_2014.pdf

Scerri, E. R. (1998): The Evolution of the Periodic System. Scientific American, 78-83. https:// www.scientificamerican.com/article/the-evolution-of-the-periodic-system/

Taylor, R. W. (2002): A 'Periodic Table' for Protein Structures. Nature, 416, 657-660. DOI: $10.1038 / 416657 \mathrm{a}$

URL1: https://www.iypt2019.org 